\title{
Choline and digestible methionine + cystine supplementation for quail in the laying phase
}

\section{Suplementação de colina e metionina + cistina digestível para codornas em fase de postura}

\author{
Dirceu Neutzling Griep Júnior ${ }^{1}$; Adriana Aparecida Pereira ${ }^{2 *}$; Gregório Murilo \\ Oliveira Júnior ${ }^{3}$; Vitor Visintin Silva de Almeida ${ }^{4}$; Edlaine Ferreira da Silva ${ }^{5}$; \\ Wilson Araújo da Silva ${ }^{6}$; Rosineide Silva de Alcântara ${ }^{6}$; Wanderson Alves da \\ Silva $^{7}$; Gilmar Silva Cardoso Júnior ${ }^{8}$; Clístenes Gomes de Oliveira ${ }^{8}$
}

\begin{abstract}
The aim of this study was to evaluate the effect of levels of choline and digestible methionine + cystine in diets for quail in the laying phase. A total of 280 Japanese laying quail were assigned to one of eight treatments in a completely randomized design in a $4 \times 2$ factorial arrangement consisting of dietary supplementation with four levels of choline $(0.0,0.042,0.084$ and $0.126 \%)$ and two levels of digestible methionine + cystine $(0.857$ and $0.685 \%)$, with five replicates and seven birds per plot. The experimental period was 84 days, represented by four 21-day evaluation cycles in which quail performance and egg quality were evaluated. There was no interaction effect between the factors for any of the studied variables, except quail weight. The highest tested levels of methionine + cystine and choline supplementation improved egg weight, feed conversion egg mass ${ }^{-1}$ and yolk percentage. By contrast, albumen percentage decreased linearly as choline inclusion in the diet was elevated. The choline supplementation levels induced a quadratic response from eggshell percentage, whose optimum result was estimated at the choline level of $0.05 \%$ in the diet. Egg specific gravity decreased linearly as choline supplementation was increased. The indicated level of digestible methionine + cystine in the diet of Japanese quail in the laying phase is $0.857 \%$, while choline should be supplemented at $0.126 \%$. Key words: Amino acid. Egg. Nutritional requirement. Performance.
\end{abstract}

\section{Resumo}

O objetivo deste estudo foi avaliar o efeito dos níveis de colina e metionina + cistina digestível em dietas para codornas em fase de postura. Um total de 280 codornas japonesas foi submetido a oito tratamentos, em delineamento inteiramente casualizado, em esquema fatorial $4 \times 2$, composto por suplementação alimentar com quatro níveis de colina $(0,0 ; 0,042 ; 0,084$ e $0,126 \%)$ e dois níveis de metionina + cistina digestível $(0,857$ e $0,685 \%)$, com cinco repetições e sete aves por parcela. O período experimental foi de 84 dias, representado por quatro ciclos de avaliação de 21 dias, em que foram avaliados o desempenho das codornas e a qualidade dos ovos. Não houve efeito de interação entre os fatores para nenhuma das variáveis estudadas, exceto o peso das codornas. Os níveis mais altos testados de suplementação com

Discente de Mestrado, Universidade Federal de Sergipe, UFS, São Cristovão, SE, Brasil. E-mail: dirceugriep@hotmail.com

2 Prof $^{a}$, Universidade Federal Alagoas, UFAL, Campus Arapiraca, Arapiraca, AL, Brasil. E-mail: adri_zoo@hotmail.com

3 Prof., UFS, São Cristovão, SE, Brasil. E-mail: gregzootec@yahoo.com.br

4 Prof., UFAL, Campus Arapiraca, Arapiraca, AL, Brasil. E-mail: vsazootec@yahoo.com.br

5 Discente de Graduação, UFAL, Campus Arapiraca, Arapiraca, AL, Brasil. E-mail: edlainesilvazoo@outlook

6 Discentes de Mestrado, UFAL, Rio Largo,AL, Brasil. E-mail: araujodasilva.wilson869@gmail.com; rs.alcantarazoo@hotmail.com Técnico, UFAL, Campus Arapiraca, Arapiraca, AL, Brasil. E-mail: wandersonzoo@live.com

8 Discentes de Mestrado, UFS, São Cristóvão, SE, Brasil. E-mail: gilmarcasdoso16@hotmail.com; clismedvet80@hotmail.com

Author for correspondence 
metionina + cistina e colina melhoraram o peso dos ovos, a conversão alimentar em massa de ovos e a porcentagem de gema. Por outro lado, a porcentagem de albumina diminuiu linearmente à medida que a inclusão de colina na dieta foi elevada. Os níveis de suplementação de colina induziram uma resposta quadrática da porcentagem de casca de ovo, cujo resultado ideal foi estimado no nível de colina de $0,05 \%$ na dieta. A gravidade específica do ovo diminuiu linearmente à medida que a suplementação de colina foi aumentada. O nível indicado de metionina + cistina digestível na dieta de codornas japonesas na fase de postura é de $0,857 \%$, enquanto a colina deve ser suplementada em $0,126 \%$.

Palavras-chave: Aminoácido. Ovo. Exigência Nutricional. Desempenho.

\section{Introduction}

To be in an adequate state of nutrition, animals must be fed balanced diets so that their feed efficiency can be maximized, reducing the amount of nutrients excreted. Therefore, the supply of a diet formulated based on the 'ideal protein' concept is crucial to increase farmer's revenue.

Methionine is considered the first limiting essential amino acid for birds. It is fundamental for their maintenance, growth, production and feather development (Klasing, 1998). Like any other amino acid, when in excess, methionine is transaminated and deaminated to methyl group and carbon chain, where it will be used for the production and storage of energy, implying higher feed costs and reduced economic return to the producer. Nonetheless, as one of the main methyl group donors in the animal metabolism, methionine is responsible for the formation of choline, cysteine, creatine, carnitine, adrenaline and melatonin (Leeson \& Summers, 2009).

Little research has been carried out with laying quail to define their methionine requirement and its interaction with choline, warranting more in-depth investigations of this possible interaction. The present study was thus conducted to evaluate the effect of levels of choline and digestible methionine + cystine in diets for Japanese quail in the laying phase on performance and egg quality.

\section{Materials and Methods}

The experiment was conducted in the Quail Farming Unit of the Department of Animal Science at the Federal University of Alagoas (UFAL), Arapiraca Campus, located in the municipality of
Arapiraca - AL, Brazil.

A total of 280 female Japanese quail (Coturnix japonica) at 150 days of age, with an average egg laying rate of $93 \%$, were assigned to one of eight treatments in a completely randomized design with five replicates, totaling 40 experimental units, with seven birds per plot.

Birds were housed in galvanized-wire cages with an area of $47 \mathrm{~cm}^{2}$ bird-1 equipped with a trough feeder and a nipple drinker. Feeders were refilled with the experimental diets twice daily, at $07 \mathrm{~h} 00$ and 16h00. Feed and water were available ad libitum.

A continuous lighting program was adopted, with $17 \mathrm{~h}$ of light provided per day ( $12 \mathrm{~h}$ of natural plus 5 $\mathrm{h}$ of artificial light) by a timer-type light controller. Curtains were managed to control drafts and the temperature inside the shed. Temperature and air relative humidity inside the shed were measured using a digital thermo-hygrometer positioned at the height of the birds, corresponding to the height of the cages, to ensure that the quail were under the same climatic conditions. Throughout the experimental period, the average maximum and minimum temperatures were 28 and $21^{\circ} \mathrm{C}$, respectively. Maximum and minimum air relative humidity was 85 and $50 \%$, respectively.

The experiment was developed in a $4 \times 2$ factorial arrangement corresponding to dietary supplementation with four levels of choline $(0.000$, $0.042,0.084$ and $0.126 \%$ ) and two digestible methionine + cystine levels $(0.857$ and $0.685 \%)$. Choline was provided in the form of choline chloride $(60 \%)$, and the digestible methionine + cystine levels were met by supplementation with 
DL-methionine (99\%). The digestible methionine + cystine level of $0.857 \%$ is proposed by the Brazilian Tables for Poultry and Swine (Rostagno et al., 2017) for 189-g Japanese quail in the laying phase, whereas the level of $0.685 \%$ was defined to be $20 \%$ lower than the requirements of these quail (Table 1).

The difference in inclusion of choline chloride between the experimental diets was offset by the use of an inert. To equate the diets for the methionine + cystine levels, corn starch was used in the treatments with the lowest level of cystine $(0.685 \%)$ to offset the difference in energy in DL-methionine.

Quail performance was evaluated at every 21 days. In the case of mortality during the period, the average intake of the plot was corrected as described by Sakomura and Rostagno (2016).

Table 1

Centesimal and calculated composition of the experimental diets (fresh-matter basis)

\begin{tabular}{|c|c|c|c|c|c|c|c|c|}
\hline \multirow{2}{*}{$\begin{array}{l}\text { Dig. Met + Cys (\%) } \\
\text { Choline (\%) }\end{array}$} & \multicolumn{4}{|c|}{0.685} & \multicolumn{4}{|c|}{0.857} \\
\hline & 0.000 & 0.042 & 0.084 & 0.126 & 0.000 & 0.042 & 0.084 & 0.126 \\
\hline \multicolumn{9}{|l|}{ Ingredient (\%) } \\
\hline Ground corn & 58.170 & 58.170 & 58.170 & 58.170 & 58.170 & 58.170 & 58.170 & 58.170 \\
\hline Soybean meal & 31.300 & 31.300 & 31.300 & 31.300 & 31.300 & 31.300 & 31.300 & 31.300 \\
\hline Dical. phosp. & 1.080 & 1.080 & 1.080 & 1.080 & 1.080 & 1.080 & 1.080 & 1.080 \\
\hline Limestone & 6.770 & 6.770 & 6.770 & 6.770 & 6.770 & 6.770 & 6.770 & 6.770 \\
\hline Soybean oil & 1.450 & 1.450 & 1.450 & 1.450 & 1.450 & 1.450 & 1.450 & 1.450 \\
\hline Common salt & 0.320 & 0.320 & 0.320 & 0.320 & 0.320 & 0.320 & 0.320 & 0.320 \\
\hline DL-methionine & 0.168 & 0.168 & 0.168 & 0.168 & 0.340 & 0.340 & 0.340 & 0.340 \\
\hline Vit. premix ${ }^{1}$ & 0.100 & 0.100 & 0.100 & 0.100 & 0.100 & 0.100 & 0.100 & 0.100 \\
\hline Min. premix ${ }^{2}$ & 0.050 & 0.050 & 0.050 & 0.050 & 0.050 & 0.050 & 0.050 & 0.050 \\
\hline Choline chl. & 0.000 & 0.070 & 0.140 & 0.210 & 0.000 & 0.070 & 0.140 & 0.210 \\
\hline L-lysine HCL & 0.017 & 0.017 & 0.017 & 0.017 & 0.017 & 0.017 & 0.017 & 0.017 \\
\hline Zinc bac. & 0.040 & 0.040 & 0.040 & 0.040 & 0.040 & 0.040 & 0.040 & 0.040 \\
\hline Starch & 0.172 & 0.172 & 0.172 & 0.172 & 0.000 & 0.000 & 0.000 & 0.000 \\
\hline Inert & 0.210 & 0.140 & 0.070 & 0.000 & 0.210 & 0.140 & 0.070 & 0.000 \\
\hline TOTAL & 100.00 & 100.00 & 100.00 & 100.00 & 100.00 & 100.00 & 100.00 & 100.00 \\
\hline \multicolumn{9}{|c|}{ Calculated composition } \\
\hline ME $\left(\mathrm{kcal} \mathrm{kg}^{-1}\right)$ & 2,800 & 2,800 & 2,800 & 2,800 & 2,800 & 2,800 & 2,800 & 2,800 \\
\hline$\overline{\mathrm{CP}(\%)}$ & 18.738 & 18.738 & 18.738 & 18.738 & 18.738 & 18.738 & 18.738 & 18.738 \\
\hline Lipid (\%) & 3.817 & 3.817 & 3.817 & 3.817 & 3.817 & 3.817 & 3.817 & 3.817 \\
\hline Av. phos. (\%) & 0.303 & 0.303 & 0.303 & 0.303 & 0.303 & 0.303 & 0.303 & 0.303 \\
\hline Calcium (\%) & 2.909 & 2.909 & 2.909 & 2.909 & 2.909 & 2.909 & 2.909 & 2.909 \\
\hline Sodium $(\%)$ & 0.145 & 0.145 & 0.145 & 0.145 & 0.145 & 0.145 & 0.145 & 0.145 \\
\hline \multicolumn{9}{|c|}{ Digestible amino acid (\%) } \\
\hline Lysine & 0.010 & 0.010 & 0.010 & 0.010 & 0.010 & 0.010 & 0.010 & 0.010 \\
\hline Methionine + Cys. & 0.007 & 0.007 & 0.007 & 0.007 & 0.007 & 0.007 & 0.007 & 0.007 \\
\hline Tryptophan & 0.002 & 0.002 & 0.002 & 0.002 & 0.002 & 0.002 & 0.002 & 0.002 \\
\hline Arginine & 0.012 & 0.012 & 0.012 & 0.012 & 0.012 & 0.012 & 0.012 & 0.012 \\
\hline Threonine & 0.006 & 0.006 & 0.006 & 0.006 & 0.006 & 0.006 & 0.006 & 0.006 \\
\hline Valine & 0.008 & 0.008 & 0.008 & 0.008 & 0.008 & 0.008 & 0.008 & 0.008 \\
\hline
\end{tabular}

${ }^{1}$ Vitamin Premix Laying - Composition per kg of feed: 1,000 mg folic acid; 1,562 mg pantothenic acid; $100 \mu \mathrm{g}$ biotin; $3,980 \mathrm{mg}$ niacin; 7,000,000 IU vit. D3; 2,000 mg vit. E; 3,000 $\mu$ g vit. B12; 4,000 mg vit. B2; 3,000 mg vit. B1; 2,100,000 IU vit. D3; 2,000 mg vit. K3; $200 \mathrm{mg}$ selenium; 100,000 mg antioxidant.

${ }^{2}$ Mineral Premix Poultry - Composition per $\mathrm{kg}$ of feed: 70,000 mg zinc (min); 1,500 mg iodine (min); 8,500 mg copper (min); 75,000 mg manganese (min); 50,000 mg iron (min); $200 \mathrm{mg}$ cobalt. 
Eggs were collected daily at $07 \mathrm{~h} 30$, and the average egg production (laying rate) in the period was determined as the number of eggs laid daily (including broken, cracked, or abnormal eggs), expressed as a percentage relative to the average number of birds housed. For the performance analyses, laying rate, feed conversion $(\mathrm{kg}$ dozen $\operatorname{eggs}^{-1}$ and $\mathrm{kg}$ egg mass ${ }^{-1}$ ) and egg weight were also measured. At the end of the experimental period, all birds were weighed to determine the difference in quail weight over the course of the experiment.

Egg quality was evaluated on the last three days of each 21-day cycle, totaling 12 days of data collection for each treatment. After the eggs were weighed, their specific gravity was determined using a density meter, by immersing all collected intact eggs in $\mathrm{NaCl}$ solutions with density ranging from 1.005 to $1.100 \mathrm{~g} \mathrm{~cm}^{-3}$, with intervals of $0.05 \mathrm{~g}$ $\mathrm{cm}^{-3}$. Eggs were classified according to their specific gravity as a function of their density. Subsequently, the three most homogeneous eggs, close to the average weight, were selected from each plot, identified and cracked for the measurements of albumen height. Albumen height was considered the distance between the surface where the egg was cracked and the intersection between the albumen and the yolk, which was measured using a digital caliper on a flat glass surface.

For the calculation of Haugh unit, egg weight was also used in addition to albumen height. Both values were substituted in the following formula to obtain the final value: $\mathrm{HU}=100 \times \log (\mathrm{H}=$ $\left.1.7 \mathrm{~W}^{0.37}+7.57\right)$, where $\mathrm{H}$ is the albumen height, in millimeters, and $\mathrm{W}$ is the egg weight, in grams (Brant, Otte, \& Norris, 1951).

The yolks were weighed individually at the moment the eggs were cracked, and shells were washed in running water, left to dry in the shade at room temperature for $48 \mathrm{~h}$ and weighed after drying. Albumen weight was determined as the difference between the egg components. Afterwards, the percentages of yolk, shell and albumen relative to the egg weight were calculated.
Eggshell thickness was measured after weighing the shell, at two distinct points in the centraltransverse area of the egg, using a $0.01-\mathrm{mm}$ graduated caliper rule (Lin et al., 2004). The value defined as the shell thickness was the average of two measurements performed in each egg.

The evaluated parameters were subjected to analysis of variance using SAS software (2003) at the $5 \%$ probability level. For the choline supplementation factor, a linear or quadratic regression analysis was performed according to the behavior of the data to determine the best level of inclusion of the nutrient in the diet.

\section{Results and Discussion}

Regarding the performance variables, no interaction effects were observed for feed intake, laying rate, feed conversion per dozen eggs, feed conversion per egg mass, or egg weight (Table 2).

This lack of effects is possibly because the quail synthesized choline in large enough amounts to maintain their performance, and the methionine level was within the nutritional requirements for that rearing stage. According to McDowell (2000), for birds in the laying period, choline can be synthesized in a sufficient amount for normal egg production.

At the methionine + cystine level of $0.685 \%$, there was an interaction effect $(p \leq 0.05)$ between the factors on final bird weight, which decreased with the increasing choline levels in the diet. At the sub-optimal digestible methionine + cystine level $(0.685 \%)$, choline supplementation is believed to have been used primarily in the conversion of essential metabolic products such as acetylcholine and phospholipids. Moreover, the lack of differences in egg production between the tested treatments may indicate some preference in the metabolism of choline into lecithin, which is a component of the egg yolk, limiting the protein turnover and negatively affecting the bird's weight. 
Table 2

Performance of quail in the laying phase as a function of supplementation with choline and digestible methionine + cystine levels

\begin{tabular}{|c|c|c|c|c|c|c|c|}
\hline Variable & $\begin{array}{c}\text { FI } \\
\mathrm{g} \mathrm{day}^{-1}\end{array}$ & $\begin{array}{c}\text { EP } \\
\text { hen } \mathrm{d}^{-1}\end{array}$ & $\begin{array}{c}\mathrm{FC} \\
\mathrm{kg} \mathrm{dz}^{-1}\end{array}$ & $\begin{array}{c}\mathrm{FC} \\
\mathrm{kg} \mathrm{kg}^{-1}\end{array}$ & $\begin{array}{c}\text { EW } \\
\mathrm{g}\end{array}$ & $\begin{array}{c}\text { IW } \\
\mathrm{g} \mathrm{bird}^{-1}\end{array}$ & $\begin{array}{c}\mathrm{FW} \\
\mathrm{g} \mathrm{bird}^{-1}\end{array}$ \\
\hline $0.000 \%$ Cho. & 26.67 & 0.94 & 0.34 & 2.45 & 11.65 & 187.50 & 183.60 \\
\hline $0.042 \%$ Cho. & 26.18 & 0.92 & 0.34 & 2.36 & 12.02 & 186.70 & 184.51 \\
\hline 0.084\% Cho. & 26.23 & 0.94 & 0.34 & 2.31 & 12.12 & 182.50 & 180.38 \\
\hline $0.126 \%$ Cho. & 26.06 & 0.92 & 0.34 & 2.34 & 12.18 & 187.20 & 178.52 \\
\hline $0.685 \%$ Met. & 26.15 & 0.93 & 0.34 & 2.37 & 11.86 & 184.85 & 177.86 \\
\hline $0.857 \%$ Met. & 26.42 & 0.92 & 0.34 & 2.36 & 12.12 & 187.27 & 185.64 \\
\hline \multicolumn{8}{|l|}{ Probability } \\
\hline Cho. & 0.83 & 0.52 & 0.91 & 0.02 & 0.03 & 0.26 & 0.01 \\
\hline Met. & 0.59 & 0.45 & 0.24 & 0.94 & 0.01 & 0.29 & 0.25 \\
\hline Cho. * Met. & 0.26 & 0.09 & 0.77 & 0.60 & 0.52 & 0.26 & 0.01 \\
\hline SDM & 0.24 & 0.68 & 0.00 & 0.02 & 0.06 & 1.73 & 2.27 \\
\hline CV $(\%)$ & 5.70 & 4.62 & 5.55 & 5.07 & 3.46 & 4.20 & 5.70 \\
\hline Reg. & - & - & - & Linear & Linear & & \\
\hline
\end{tabular}

Cho. $=$ choline Met $=$ methionine + digestible cystine; $\mathrm{FI}=$ feed intake $; \mathrm{EP}=$ eggs produced $\mathrm{FC}=$ feed conversion; $\mathrm{EW}=$ egg weight; IW = initial weight; $\mathrm{FW}=$ final weight; $\mathrm{CV}=$ coefficient of variation; $\mathrm{SDM}=$ standard deviation of the mean; Reg. = polynomial regression.

Studies conducted by Reis et al. (2011) showed that the weight of Japanese quail was kept constant with the inclusion of choline in diets containing $0.84 \%$ methionine. This finding reinforces the hypothesis that dietary choline levels may influence bird performance and that it is essential to adjust the adopted level to the methionine concentration in the diet.

Treatments did not affect $(\mathrm{p}>0.05)$ feed intake, laying rate, or feed conversion per dozen eggs. However, both the digestible methionine + cystine and choline levels provided an increase $(p \leq 0.05)$ in egg weight.

In this respect, the digestible methionine + cystine level of $0.857 \%$ increased egg weight by $2.2 \%$ (11.86 vs. $12.12 \mathrm{~g}$ ). However, these findings differ from those obtained by Castro et al. (2011), who tested two levels of methionine, 0.65 and $0.75 \%$, and did not observe significant differences for egg weight, in quail.

This difference in relation to the above mentioned studies is possibly because the levels tested by those authors were sub-optimal, in most cases being lower than the lowest methionine level evaluated in this study. Because methionine is the first limiting amino acid for birds, when supplied in sub-optimal quantities, it may limit protein synthesis-in this case, for egg production-, consequently reducing its weight. Additionally, there are possible differences in terms of the species evaluated, since most studies investigated laying hens.

As the choline level was increased $(\mathrm{p} \leq 0.05)$ from 0.042 to $0.126 \%$, egg weight also increased, as demonstrated by the following equation: Egg weight $(g)=11.738+4.0452$ Cho $\left(\mathrm{R}^{2}=0.84\right)$. With choline supplementation, methionine availability likely rose, thereby increasing egg size, since this amino acid is a component of proteins. In the case of quail, the National Research Council [NRC] (1994) also suggests that choline be supplemented at $0.110 \%$ in the diet for egg size to be maintained.

Feed conversion per egg mass improved $(\mathrm{p} \leq 0.05)$ as the choline inclusion level was elevated, as shown by the following equation: $\mathrm{FC}$ egg mass $^{-1}=2.4219$ 
$=0.9071$ Cho $\left(\mathrm{R}^{2}=0.70\right)$. This result is possible, considering that all quail had the same feed intake; however, egg weight increased with the choline levels. This finding suggests that, at the same feed intake level, a larger egg mass was produced as the choline inclusion levels were elevated.

Results similar to those obtained in this study were reported by Castro et al. (2011), who observed improved production performance in quail supplemented with $600 \mathrm{ppm}$ choline at the methionine level of $0.75 \%$. Choline is used for vital processes in the animal metabolism; e.g., as a constituent of the cell membrane and in the nervous systems. In this way, if the organism requires it, this product can be derived from some precursor such as methionine. Thus, when the diet supplemented with choline, a larger amount of methionine may be available for the reproductive organs, influencing egg weight, in this case. These results disagree with those published by Vasconcelos et al. (2013) and Reis et al. (2012), who did not observe differences in egg weight following the inclusion of 240 to 1500 $\mathrm{mg}$ choline $\mathrm{kg}$ diet $^{-1}$, in quail.

No differences were observed for the interaction between methionine + digestible cystine and choline for Haugh unit, eggshell thickness, specific gravity, or eggshell, yolk and albumen percentages (Table 3). The same response was observed for the methionine + digestible cystine levels in the diet $(p \geq 0.05)$. Likewise, the dietary choline levels did not influence Haugh unit or shell thickness. Factors such as the time and place of egg storage, bird age, aptitude, nutrition, disease and supplementation with vitamins $\mathrm{C}$ or $\mathrm{E}$ (Ahmadi \& Rahmini, 2011) can interfere with the internal and external quality of eggs. However, in the current study, these sources of variation were similar between treatments, exerting a lesser or no effect on these variables.

\section{Table 3}

Quail egg quality and percentage of excreted nitrogen as a function of supplementation with choline and digestible methionine + cystine levels

\begin{tabular}{|c|c|c|c|c|c|c|}
\hline Variable & $\begin{array}{c}\text { Haugh } \\
\text { unit }\end{array}$ & $\begin{array}{c}\mathrm{ST} \\
\mathrm{mm}\end{array}$ & $\begin{array}{c}\mathrm{SG} \\
\mathrm{g} \mathrm{cm}^{-3}\end{array}$ & $\begin{array}{c}\text { Shell } \\
\mathrm{kg} \mathrm{kg}^{-1}\end{array}$ & $\begin{array}{c}\text { Yolk } \\
\mathrm{kg} \mathrm{kg}^{-1}\end{array}$ & $\begin{array}{c}\text { Albumen } \\
\mathrm{kg} \mathrm{kg}^{-1}\end{array}$ \\
\hline $0.000 \%$ Cho. & 91.97 & 0.22 & 1.081 & 0.083 & 0.295 & 0.622 \\
\hline $0.042 \%$ Cho. & 91.91 & 0.21 & 1.080 & 0.083 & 0.303 & 0.617 \\
\hline 0.084\% Cho. & 91.74 & 0.22 & 1.080 & 0.084 & 0.304 & 0.614 \\
\hline $0.126 \%$ Cho. & 91.73 & 0.22 & 1.078 & 0.081 & 0.308 & 0.610 \\
\hline $0.685 \%$ Met. & 91.81 & 0.22 & 1.080 & 0.082 & 0.303 & 0.615 \\
\hline $0.857 \%$ Met. & 91.86 & 0.22 & 1.080 & 0.082 & 0.302 & 0.616 \\
\hline \multicolumn{7}{|l|}{ Probability } \\
\hline Cho. & 0.63 & 0.61 & 0.01 & 0.02 & 0.01 & 0.01 \\
\hline Met. & 0.77 & 0.71 & 0.24 & 0.72 & 0.64 & 0.69 \\
\hline Cho. * Met. & 0.99 & 0.53 & 0.95 & 0.53 & 0.57 & 0.70 \\
\hline SDM & 0.22 & 0.00 & 0.00 & 0.27 & 0.15 & 0.16 \\
\hline CV (\%) & 1.56 & 3.89 & 0.18 & 0.04 & 3.08 & 1.62 \\
\hline Reg. & - & - & Linear & Quad. & Linear & Linear \\
\hline
\end{tabular}

Cho. $=$ choline; Met = methionine + digestible cystine; $\mathrm{ST}=$ shell thickness; $\mathrm{SG}=$ specific gravity; $\mathrm{CV}=$ coefficient of variation; $\mathrm{SDM}=$ standard deviation of the mean; Reg. = polynomial regression; Quad.= quadratic. 
According to King'ori (2011), eggshell thickness can be influenced by several factors, including minerals such as calcium, magnesium and phosphorus, as the main inorganic components of the eggshell. Thus, similar eggshell thickness values were observed in the current study because the diets had similar $\mathrm{Ca}$ and $\mathrm{P}$ contents, which is also reinforced by the fact that the birds showed the same feed intake and laying rate.

Specific gravity decreased linearly $(\mathrm{p} \leq 0.05)$ with the increasing choline levels in the diet, as shown by the following equation: Specific gravity $=1.0813$ $=0.0214$ Cho $\left(\mathrm{R}^{2}=0.84\right)$. Increasing dietary choline levels led to a reduction in egg specific gravity and, consequently, less dense eggs as a function of the yolk percentage, since these eggs probably showed a higher percentage of fat, which is less dense.

Eggshell percentage responded quadratically $(\mathrm{p} \leq 0.05)$, as can be seen in the following equation: Egg shell $(\%)=8.2235+4.6893 \mathrm{Cho}=46.91 \mathrm{Cho}^{2}$ $\left(\mathrm{R}^{2}=0.81\right)$. The optimal estimated choline level in the diet for this variable was $0.050 \%$, corresponding to $8.341 \%$ of eggshell. The difference in eggshell percentagemayberelated to the increasing percentage of another egg structure in the present case, the yolk size, since albumen percentage decreased as choline was increased, whereas eggshell thickness was not affected by the treatments. Similar results were reported by Khairani and Wiryawan (2016), who found that diets without choline supplementation lead to a higher eggshell percentage compared to choline-supplemented diets.

Yolk percentage increased linearly $(\mathrm{p} \leq 0.05)$, indicating that higher choline inclusion levels provide higher amounts of this component, as seen in the following equation: Yolk $(\%)=$ $29.6256+9.8595$ Cho $\left(\mathrm{R}^{2}=0.90\right)$. The increased yolk percentage was likely because choline is one of the main components in the formation of phosphatidylcholine, which includes $76 \%$ of the total phospholipids from the egg yolk (Houpalahti, Fandino, Anton, \& Schade, 2007). This is also one of the explanations for the higher egg weight obtained in these treatments.

Another product of choline in the metabolism is lecithin, which participates in the absorption and transport of liver fat; i.e., it improves the lipid mobilization for the maturation of the follicle, which will originate the yolk, directly affecting egg weight.

Albumen percentage decreased $(\mathrm{p} \leq 0.05)$ as the choline levels in the diet were elevated, as demonstrated by the following equation: Albumen $(\%)=62.1194-8.7679$ Cho $\left(\mathrm{R}^{2}=0.99\right)$.

The sum of egg components was represented in percentage values; therefore, a reduction in one component in this case, the albumen, is inversely proportional to an increase in the other in the present case, the yolk. Furthermore, results suggest that choline improves metabolism efficiency, providing larger amounts of methionine for the synthesis of egg protein, resulting in the production of heavier eggs.

Betaine, folacin and vitamin $\mathrm{B} 12$, or the combination of different levels and composition of fat, carbohydrate and protein in the diet, as well as age, sex, caloric intake and animal growth rate, can influence the lipotropic action of choline and, consequently, its requirement (Mcdowell, 2000). All of these factors support the divergent results regarding the recommended level of choline for performance and egg quality characteristics.

On these bases, for Japanese quail in the laying phase, the digestible methionine + cystine level of $0.857 \%$ is indicated to improve egg weight and the choline supplementation level of $0.126 \%$ is recommended to obtain heavier eggs and egg components and better feed conversion per egg mass. 


\section{References}

Ahmadi, F. \& Rahmini, F. (2011). Factors affecting quality and quantity of egg production in laying hens: a Review. World Applied Sciences Journal, 12(3), 327-384.

Brant, A. W., Otte, A. W., \& Norris, K. H. (1951). Recommend standards for scoring and measuring opened egg quality. Food Technology, 5, 356-361

Castro, S. F., Fortes, B. D. A., Carvalho, J. C. C., Bertechini, A. G., Queiroz, L. S. B., \& Garcia, A. A. P. Jr. (2011). Methionine ratio and dietary choline on the performance of japanese quail (Coturnix coturnix japonica) in laying. Ciência Animal Brasileira, 12(4), 635-641. doi: 10.5216/cab.v12i4.9976

Houpalahti, R., Fandino, R. L., Anton, M., \& Schade, R. (2007). Bioactive egg compound. New York: Springer.

Leeson, S., \& Summers, J. D. (2009). Commercial poultry nutrition (3nd ed.). Guelph: Nottingham University Press.

Khairani, S., \& Wiryawan, K. G. (2016). Egg production and quality of quails fed diets with varying levels of methionine and choline chloride. Media Peternakan, 39(1), 34-39. doi: 10.5398/medpet.2016.39.1.34

King'ori, A. M. (2011). A review of the uses of poultry eggshells and shell membranes. International Journal of Poultry Science, 10(11), 908-912. doi: 10.3923/ijps.2011.908.912

Klasing, K. C. (1998). Comparative avian nutrition. New York: $\mathrm{CAB}$ international.

Lin, H., Mertens, K., Kemps, B., Govaerts, T., Ketelaere, B., Baerdemaeber, J.,... Buyse, J. (2004). New approach of testing the effect of heat stress on eggshell quality: mechanical and material properties of eggshell and membrane. British Poultry Science, 45(4), 476-482. doi: 10.1080/00071660400001173
McDowell, L. R. (2000). Vitamin in animal and human nutrition (2nd ed.). Ames: Iowa State University Press.

National Research Council. (1994). Nutrient requirements of poultry (9nd ed.). Washington: National Academy of Science.

Reis, R. S., Barreto, S. L. T., Gomes, P. C., Lima, H. J. D., Medina, P. M., \& Ferreira, F. (2011). Relationship of methionine plus cystine with lysine in diets for laying japanese quails. Revista Brasileira de Zootecnia, 40(5), 1031-1037. doi: 10.1590/S151635982011000500014

Reis, R. S., Barreto, S. L. T., Paula, E., Muniz, J. C. L., Viana, G. S., Mencalha, R., \& Barbosa, L. M. $R$. (2012). Supplementation of choline in the diet of japanese laying quails. Revista Brasileira de Agropecuária Sustentável, 2(1), 118-123.

Rostagno, H. S. Albino, L. F. T., Hannas, M. I., Donzele, J. L., Sakomura, N. K., Perazzo, F. G.,... Brito, C. O. (2017). Tabelas brasileiras para aves e suínos: composição de alimentos e exigências nutricionais. (4a ed.). Viçosa: Editora UFV.

Sakomura, N. K., \& Rostagno, H. S. (2016). Métodos de pesquisa em nutrição de monogástricos (2a ed.). Jaboticabal: Funep.

SAS. (2003). Institute Inc. SAS Online Doc ${ }^{\circledR}$. Version 8. SAS Institute Inc. Cary, NC.

Vasconcelos, R. J. C., Baião, N. C., Lara, L. J. C., Ecco, R., Machado, A. L. C., Pompeu, M. A.,... Miranda, D. J. A. (2013). The effects of choline supplementation on the performance of commercial laying hens. Arquivo Brasileiro de Medicina Veterinária e Zootecnia, 65(4), 1116-1122. doi: 10.1590/S010209352013000400026 